\title{
FAKTOR YANG MEMPENGARUHI KEPUASAN KERJA PEGAWAI NEGERI SIPIL DI KOTA BEKASI
}

\author{
Dian A. Rahim *) \\ *) Dosen Program Studi Manajemen Unsada \\ Fakultas Ekonomi Universitas Darma Persada Jakarta Timur \\ e-mail : dian.rahim21@gmail.com
}

\begin{abstract}
The purpose of this research is to find out what influence factors of job satisfaction for the government emplorees at Bekasi City The data is collected by distributing questionnaires to 105 respondents of the employees at Bekasi City, based on random sampling. The analytical tool for this research is analysis factor. The results shows that, from the 20 variables, there are 5 factors is formed with the highest eigenvalue, which is organizational culture, how to work, work condition, communication and work supervision.
\end{abstract}

Keywords: Job satisfaction, government employees, factor analisys

\section{PENDAHULUAN}

Efektifitas dan efisiensi suatu perusahaan sangat ditentukan oleh kualitas sumber daya manusia, sehingga pengelolaan sumber daya manusia haruslah dilakukan dengan baik, sehingga dapat menghasilkan sumber daya manusia yang berkualitas yang tentunya akan memberi keuntungan besar bagi organisasi atau perusahaan. Sebesar apapun usaha dari organisasi untuk meningkatkan kualitas tenaga kerja, tetapi bila tidak didukung oleh tenaga sumber daya manusia itu sendiri, maka tidak akan ada artinya. Oleh karena itu, antara pihak organisasi dan pihak tenaga kerja harus ada kerjasama satu sama lain. Organisasi atau perusahaan tidak dapat melakukan aktivitas tanpa adanya tenaga sumber daya manusia begitu juga sebaliknya. Dalam setiap organisasi terdapat dua pihak yang saling berkepentingan dan memiliki ketergantungan satu sama lain, yaitu organisasi itu sendiri dan pegawai atau pegawai. Biasanya diantara keduanya terdapat persepsi yang berbeda. Pegawai mengiginkan gaji, insentif dan fasilitasfasilitas yang layak dari organisasi, sedangkan organisasi menginginkan agar pegawai dapat bekerja sesuai dengan yang diharapkan. Setiap pegawai dalam mencapai tujuan organisasi akan timbul adanya perasaan puas dan tidak puas dalam bekerja. Oleh karena itu, perlu adanya organisasi yang sehat secara etis bagi pegawai yang diciptakan dalam suatu organisasi, dimana kepuasan kerja merupakan hal yang penting dimiliki oleh setiap pegawai dalam organisasi. Ganyang (2018) menjelaskan bahwa kepuasan kerja merupakan perasaan yang dimiliki oleh pegawai terhadap pekerjaannya, baik berupa perasaan yang menyenangkan maupun tidak menyenangkan. Dengan dimilikinya kepuasan kerja pada diri seseorang pegawai dalam bekerja akan lebih memacu partisipasinya dalam setiap kegiatan mencapai tujuannya, hal ini karena adanya perilaku individu dalam 
organisasi yang merupakan interaksi antara karakteristik individu dan karakteristik organisasi.

Pegawai Negeri Sipil (PNS) di Kota Bekasi pada dasarnya merupakan unsur pendukung tugas pemerintah daerah dalam melayani masyarakat. Kinerja para PNS juga ditentukan oleh kepuasan mereka dalam menjalankan pekerjaan. Beberapa faktor yang menjadi penentu dalam kepuasan kerja PNS di Kota Bekasi adalah kesempatan untuk maju, keamanan bekerja, gaji, institusi dan manajemen, pengawasan dan atasan, kondisi kerja, aspek sosial dalam bekerja, komunikasi serta fasilitas (Gambar 1).

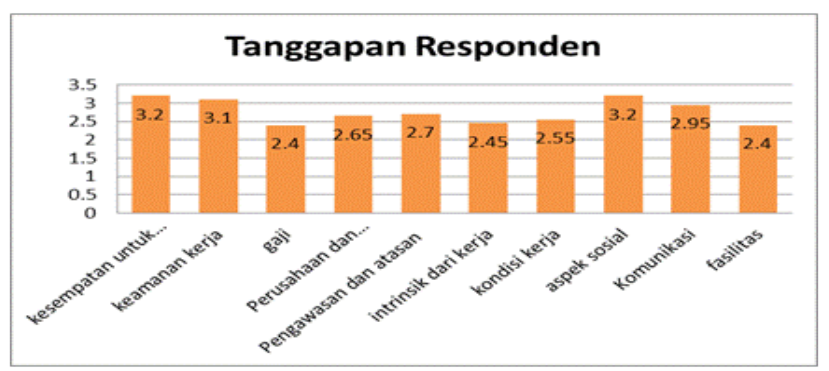

Gambar-1: Kepuasan kerja PNS kota Bekasi 2010

Gambar-1 menjelaskan bahwa ada 4 kriteria tingkat kepuasan yang digunakan dalam penelitian ini yaitu tidak puas $(0$ $0.8)$, kurang puas $(0.9-1.6)$, puas $(1.7-$ 2.4) dan sangat puas (2.5 - 3.2) yang digunakan dalam identifikasi awal. Hasil pengumpulan data awal dan dijabarkan dengan 4 kriteria tersebut, diketahui secara umum PNS di kota Bekasi sangat puas pada kesempatan untuk maju, keamanan bekerja, institusi dan manajemen, pengawasan dan atasan, kondisi kerja, aspek sosial dalam bekerja serta komunikasi. Beberapa responden merasa puas yaitu pada gaji dan fasilitas kerja.

\section{LANDASAN TEORI}

\section{Manajemen Sumber Daya Manusia}

Desseler (2015) menjabarkan bahwa manajemen sumber daya manusia adalah proses untuk memperoleh, melatih, menilai, dan mengompensasi pegawai dan untuk mengurus relasi tenaga kerja, kesehatan dan keselamatan, serta hal-hal yang berhubungan dengan keadilan. Sejalan dengan pemikiran Desseler tersebut, Sutrisno menjelaskan (2017) bahwa manajemen sumber daya manusia adalah pendayagunaan, pengembangan, penelitian, pemberian balas jasa dan pengelolaan individu anggota organisasi atau kelompok pekerja. Pada sisi yang berbeda, Badriyah (2017) melihat manajemen sumber daya manusia sebagai bagian ilmu manajemen yang memfokuskan perhatian pada peraturan peranan sumber daya manusia dalam kegiatan suatu organisasi. Dari beberapa definisi tersebut, dapat disimpulkan manajemen sumber daya manusia adalah suatu bidang manajemen yang khusus mempelajari hubungan dan peranan manusia dalam organisasi. Fokus yang dipelajari dalam manajemen sumber daya manusia hanyalah masalah yang berhubungan dengan tenaga kerja saja, baik secara individu maupun hubungan antar tenga kerja.

Namun jika dilihat secara fungsi, Flippo (2013) melihat sumber daya manusia memiliki 2 (dua) fungsi yaitu pertama sebagai fungsi manajerial; dimana dalam fungsi ini mencakup planning, organizing, directing dan controlling. 
Fungsi kedua menurut Flippo, manajemen sumber daya manusia lebih mengarah pada sistem operasional. Fungsi ini mencakup (1) pengadaan pegawai meliputi penentuan kebutuhan pegawai, penarikannya, seleksi dan penempatan; (2) pengembangan pegawai meliputi pembinaan dan peningkatan kapasitas pegawai yang tujuan akhirnya adalah meningkatkan kemampuan pegawai; (3) kompensasi meliputi tunjangan atau tambahan penghasilan lainnya; (4) pengintegrasian meliputi penyelarasan sikap pegawai dengan tujuan perusahaan atau institusi; (5) pemeliharaan meliputi usaha untuk mempertahankan dan meningkatkan kondisi yang telah ada; yang terakhir adalah (6) pensiunan meliputi pemberian jaminan hari tua kepada pegawai baik dalam bentuk jaminan kesehatan pasca masa kerja ataupun pemberian insentif bulanan.

\section{Kepuasan Kerja}

Secara teori, kepuasan kerja digambarkan sebagai suatu kondisi yang menghasilkan kesenangan atas pekerjaan yang dilakukan (Hamali; 2018). Secara rinci teori kepuasan kerja dijelaskan sebagai berikut: 1). Teori nilai (value theory); konsep teori ini kepuasan kerja terjadi pada tingkatan dimana hasil pekerjaan diterima individu seperti diharapkan. Semakin banyak orang menerima hasil, akan semakin puas. Semakin sedikit mereka menerima hasil, akan kurang puas. Teori nilai memfokuskan pada hasil mana pun yang menilai orang tanpa memperhatikan siapa mereka. Dengan menekankan nilai-nilai, teori ini menganjurkan bahwa kepuasan kerja dapat diperoleh dari banyak faktor (Hamali ; 2018). 2). Teori dua faktor (two factor theory); teori dua faktor merupakan teori kepuasan kerja yang mengajurkan bahwa kepuasan (satisfaction) dan ketidak puasan (dissatisfaction) merupakan bagian dari kelompok variabel yang berbeda, yaitu motivator dan hygiene factor. 3).Teori keseimbangan (equity theory); teori ini menjabarkan tentang keseimbangan yang didapat pegawai berupa: input is anything of value that employee perceives that he contributed to his job, outcome is anything of value the employee perceives he obtains from the job, comparison person may be someone in the same organization, someone in a different organization, or even the person himself in a previous job (Sinambela; 2016)

\section{Faktor yang Mempengaruhi Kepuasan Kerja}

Kepuasan kerja memiliki faktorfaktor yang berpengaruh. Sutrisno (2017) dalam salah satu tulisannya menjelaskan, faktor-faktor itu adalah: 1). Kesempatan untuk maju. Dalam hal ini ada tidaknya kesempatan untuk memperoleh pengalaman dan peningkatan kemampuan selama kerja. 2). Keamanan kerja. Faktor ini disebut sebagai penunjang kepuasan kerja karena keadaan yang aman sangat mempengaruhi perasaan pegawai selama kerja. 3). Gaji. Gaji merupakan penyebab puas atau tidakpuas seseorang dalam bekerja. Tidak jarang orang mengekspresikan kepuasan kerjanya dengan sejumlah uang yang diperoleh. 4). Perusahaan dan manajemen. Perusahan dan manjemen yang baik mampu memberikan situasi dan kondisi kerja yang stabil. 5). Pengawasan dan atasan. Supervisi yang buruk dapat berakibat pada rendahnya kehadiran dan tingginya turn over. 6). Faktor intrinsik dari pekerjaan. Atribut yang ada dalam pekerjaan mensyaratkan keterlampilan tertentu. Sukar dan mudahnya serta kebanggaan akan tugas dapat meningkatkan atu mengurangi kepuasan. 7). Kondisi kerja. Termasuk kondisi tempat, ventilasi, penyiaran, kantin, dan tempat parkir. 8). Aspek sosial dalam bekerja. Aspek ini merupakan salah satu sikap yang sulit di gambarkan tetapi 
dipandang sebagai faktor yang menunjang puas atau tidak puasnya dalam bekerja. 9). Komunikasi. Komunikasi yang lancar antarpegawai dengan pihak manajemen banyak dipakai alasan untuk menyukai jabatannya. Dalam hal ini adanya kesediaan pihak atasan untuk mau mendengar, memahami, dan mengakui pendapat ataupun prestasi pegawai sangat berperan dalam menimbulkan rasa puas terhadap kerja. 10). Fasilitas. Fasilitas yang dimaksud disini adalah rumah sakit, izin cuti, dana pensiun, atau perumahan merupakan standar suatu jabatan dan apabila dapat dipenuhi maka akan menimbulkan rasa puas.

\section{Mengukur Kepuasan Kerja}

Wibowo (2016) menjelaskan bahwa pekerja atau pegawai pada dasarnya memerlukan interaksi dengan sesama teman kerja dan atasan, mengikuti aturan dan kebijaksanaan organisasi, serta berharap dapat mencapai standar kinerja. Hal ini juga menjelaskan bahwa penilaian pekerja tentang puas atau tidak puas terhadap pekerjaan merupakan suatu hal yang sangat kompleks. Terdapat dua macam pendekatan yang secara luas dipergunakan untuk melakukan pengukuran kepuasan kerja berdasarkan pemikiran Robbins (2016), yaitu sebagai berikut: 1). Single global rating, yaitu suatu pertanyaan global atau umum untuk menggambarkan seberapa puas seseorang terhadap pekerjaannya. Responden diberi 2 (dua) kemungkinan jawaban yaitu highly statisfied dan highly disstatisfied.

2). Summation score yaitu pertanyaan yang lebih mengeksplorasi perasaan pegawai, yaitu dengan cara mengidentifikasikan elemen penting dalam pekerjaan dan menyatakan perasaan pekerja tentang masing-masing elemen. Faktor spesifik yang diperhitungkan adalah: sifat pekerjaan, supervisi, upah sekarang, kesempatan promosi dan hubungan dengan se3sama rekan kerja. 3). Summing up yaitu merespon perasaan terhadap sejumlah faktor kerja untuk kemudian memberikan feedback.

\section{Mengungkapkan Ketidakpuasan Kerja}

Robbins et al (2015) menjelaskan bahwa ketidakpuasan dapat diekspresikan dalam beberapa cara, antara lain: 1). Keluar (exit) dari perusahaan. Perilaku yang diarahkan untuk meninggalkan organisasi, meliputi mencari posisi baru juga mengundurkan diri. 2). Bersuara (voice) untuk menyatakan ketidakpuasan. Secara aktif dan kontruktif berusaha memperbaiki kondisi, meliputi menganjurkan perbaikan, mendiskusikan permasalahan dengan atasan dan beberapa bentuk serikat kerja.

3). Loyalitas tetap terjaga. Positif tapi optimis menunggu kondisi mengalami perbaikan, meliputi berbicara lantang untuk organisasi dalam menghadapi kritikan eksternal dan mempercayai organisasi serta manajemennya bertindak secara efektif. 4). Mengabaikan (neglect) segala kondisi perusahaan. Secara pasif membiarkan keadaan semakim memburuk, meliputi kemangkiran atau keterlambatan yang kronik, usaha kerja yang menurun dan tingkat kesalahan yang meningkat.

\section{Kerangka Pemikiran}


Kerangka pemikiran dalam penelitian ini adalah;

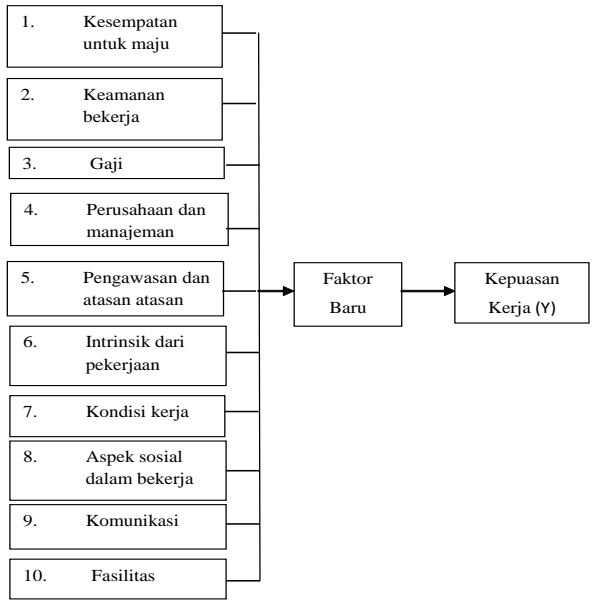

\section{Gambar 2 . Kerangka Pemikiran}

\section{Hipotesis}

Hipotesis adalah jawaban sementara terhadap rumusan penelitian, dimana rumusan penelitian telah dinyatakan dalam bentuk kalimat pernyataan. Penolakan atau penerimaan suatu hipotesis tersebut tergantung dari hasil penelitian terhadap faktor-faktor yang dikumpulkan, kemudian diambil satu kesimpulan. Hipotesis dalam penelitian ini adalah : faktor-faktor kepuasan kerja pada pegawai negeri sipil (PNS) kota Bekasi adalah

\section{METODE PENELITIAN}

Metode penelitian yang digunakan dalam penelitian ini adalah dengan metode assosiatif dan analisis faktor konformatori. Definisi metode penelitian asosiatif menurut Sugiyono (2017) adalah penelitian yang bertujuan untuk mengetahui pengaruh ataupun juga hubungan antara dua variabel atau lebih.

Analisis faktor adalah suatu cara pengkalsteran faktor-faktor, kemudian menjadi suatu faktor baru. Analisis faktor Konfirmatori memiliki tujuan untuk mengetahui apakah variabel budaya organisasi, cara kerja, kondisi kerja, kesempatan untuk maju, keamanan bekerja, gaji, perusahaan dan manajmen, pengawasan dan atasan, intrinsik dari pekerjaan, kondisi kerja, aspek sosial dalam bekerja, komunikasi dan fasilitas. Adapun hipotesis adalah: $\mathrm{H}_{0}=$ sampel atau variabel belum memadai untuk dianalisis lebih lanjut, dan $\mathrm{H}_{1}=$ sampel atau variabel sudah memadai untuk dianalisis lebih lanjut. komunikasi dan pengawasan berpengaruh terhadap kepuasan kerja pegawai negeri sipil di Kota Bekasi. Supranto (2010) menyatakan analisis faktor merupakan nama umum yang menunjukan suatu kelas prosedur, utamanya dipergunakan untuk mereduksi data atau meringkas dari variabel yang banyak diubah menjadi 4 atau 5 variabel baru yang disebut faktor dan masih memuat sebagaian besar informasi yang terkandung dalam variabel asli (original variable). Dasar model analisis faktor dapat dijabarkan ke dalam bentuk model persamaan adalah sebagai berikut:

$$
X i=B i 1 . F 1+B i 2 . F 2+\cdots+B i m . F m+V i . \mu i
$$


dimana :

$$
\begin{aligned}
\mathrm{Xi}= & \text { Variabel ke-i yang dibakukan } \\
& \text { (rata-ratanya nol, standar } \\
& \text { deviasinya satu) } \\
\mathrm{Bij}= & \text { Koefisien regresi parsial yang } \\
& \text { dibakukan untuk variabel } \mathrm{i} \text { pada } \\
& \text { common factor } \text { ke-j. } \\
\mathrm{Fj}= & \text { Common factor ke-j. } \\
\mathrm{Vi}= & \text { Koefisien regresi yang dibakukan } \\
& \text { untuk variabel ke-i pada faktor } \\
& \text { yang unik ke-i (unique factor }) . \\
\mu \mathrm{i}= & \text { faktor unik variabel ke-i. } \\
\mathrm{m}= & \text { Banyaknya common factor. }
\end{aligned}
$$

Populasi dalam penelitian ini adalah Pegawai Negeri Sipil di Kota Bekasi. Sementara sampel yang digunakan sebanyak 105 orang tersebar pada berbagai divisi yang diambil secara acak. Teknik pengambilan sampel pada penelitian ini menggunakan, metode Probability Sampling yaitu dengan Purposive Sampling. Menurut Sugiyono (2017) Probability Sampling yaitu teknik pengambilan sampel yang memberikan peluang atau kesempatan sama bagi setiap unsur atau anggota populasi untuk dipilih menjadi sampel.

\section{HASIL DAN PEMBAHASAN}

\section{KMO dan Bartlett's Test}

Pada pengujian awal digunakan uji KMO (Kaiser-Meyer-Olkin) and Bartlett. Pengujian ini digunakan untuk mengetahui variabel dan sampel yang bisa dianalisis dengan menggunakan analisis faktor. KaiserMeyer-Olkin and Bartlett's Test sebesar 0,748 dengan signifikan sebesar 0,000, karena angka KMO tersebut sudah di atas 0,50 dan signifikansi jauh di bawah $(0,000<0,05)$, maka variabel dan sampel yang ada sudah bisa dianalisis dengan menggunakan analisis faktor.

Berdasarkan hipotesis dan hasil awal KMO dan Bartlett's Test angka Measure of Sampling Adequacy (MSA) berkisar antara 0 sampai dengan 1, sesuai dengan kriteria, jika angka MSA $=1$, maka ada variabel yang lain dan variabel tersebut tidak bisa diprediksi. Jika angka MSA > 0,5 maka variabel tersebut bisa di prediksi dan dianalisis lebih lanjut. Jika MSA < 0,5 variabel tidak bisa diprediksi dan tidak bisa dianalisis lebih lanjut, sehingga harus dikeluarkan dari variabel lainnya. Hasil uji menjelaskan bahwa angka MSA seluruh variabel di atas 0,5, seperti terlihat dalam Tabel-1.

Tabel-1: Angka Kaiser-Meyer-Olkin 


\begin{tabular}{|c|c|c|c|}
\hline No & Variabel & KMO & Standar \\
\hline 1 & Kesempatan memperoleh pengalaman & 0,661 & 0,500 \\
\hline 2 & $\begin{array}{l}\text { kesempatan menigkatkan kemampuan } \\
\text { kerja }\end{array}$ & 0,838 & 0,500 \\
\hline 3 & keamanana bekerja & 0,735 & 0,500 \\
\hline 4 & Kenyamanan bekerja & 0,845 & 0,500 \\
\hline 5 & Gaji menyebabkan ketidakpuasan & 0,664 & 0,500 \\
\hline 6 & $\begin{array}{l}\text { Jarangnya mengekspresikan kepuasan } \\
\text { dengan sejumlah uang }\end{array}$ & 0,825 & 0,500 \\
\hline 7 & $\begin{array}{ll}\text { Perusahaan dan manajeman } & \text { yang } \\
\text { memberikan situasi stabil } & \end{array}$ & 0,828 & 0,500 \\
\hline 8 & Penilaian instansi promosi jabatan & 0,599 & 0,500 \\
\hline 9 & Supervisi atau pengawasan & 0,520 & 0,500 \\
\hline 10 & $\begin{array}{l}\text { Etika atasan menginstruksikan pegawai } \\
\text { dengan baik }\end{array}$ & 0,702 & 0,500 \\
\hline 11 & Atribut mensyaratkan status tertentu & 0,862 & 0,500 \\
\hline 12 & Sukar dan Mudahnya Mendapatkan tugas & 0,812 & 0,500 \\
\hline 13 & Lingkungan Kerja & 0,816 & 0,500 \\
\hline 14 & Pelatihan & 0,792 & 0,500 \\
\hline 15 & $\begin{array}{l}\text { Sikap menunjang rasa puas atau tidak } \\
\text { puas }\end{array}$ & 0,834 & 0,500 \\
\hline 16 & Team work & 0,776 & 0,500 \\
\hline 17 & Komunikasi antar pegawai dan atasan & 0,608 & 0,500 \\
\hline 18 & $\begin{array}{llll}\begin{array}{l}\text { Atasan } \\
\text { pegawai }\end{array} & \text { mendengar } & \text { dan } & \text { memahami } \\
\end{array}$ & 0,703 & 0,500 \\
\hline 19 & Hari libur & 0,691 & 0,500 \\
\hline 20 & Askes, cuti dan dana pensiun & 0,631 & 0,500 \\
\hline
\end{tabular}

Sumber : Data diolah

\section{Communalities}

Communalities adalah jumlah varian faktor yang ada. Tabel-2 berikut menjelaskan dari suatu variabel yang bisa di jelaskan oleh communalities dari variabel yang diteliti.

Tabel-2: Communalities dari variabel

\begin{tabular}{|c|l|r|c|}
\hline No & \multicolumn{1}{|c|}{ Variabel } & Initial & Extraction \\
\hline 1 & Kesempatan memperoleh pengalaman $\mathrm{X}_{1}$ & 1.000 & .707 \\
\hline 2 & $\begin{array}{l}\text { kesempatan menigkatkan kemampuan } \\
\text { kerja } \mathrm{X}_{2}\end{array}$ & 1.000 & .629 \\
\hline 3 & keamanana bekerja $\mathrm{X}_{3}$ & 1.000 & .620 \\
\hline 4 & Kenyamanan bekerja $\mathrm{X}_{4}$ & 1.000 & .727 \\
\hline 5 & Gaji menyebabkan ketidakpuasan $\mathrm{X}_{5}$ & 1.000 & .393 \\
\hline 6 & $\begin{array}{l}\text { Jarangnya mengekspresikan kepuasan } \\
\text { dengan sejumlah uang } \mathrm{X}_{6}\end{array}$ & 1.000 & .620 \\
\hline 7 & $\begin{array}{l}\text { Perusahaan dan manajeman yang } \\
\text { memberikan situasi stabil } \mathrm{X}_{7}\end{array}$ & 1.000 & .576 \\
\hline 8 & Penilaian instansi promosi jabatan $\mathrm{X}_{8}$ & 1.000 & .552 \\
\hline 9 & Supervisi atau pengawasan $\mathrm{X}_{9}$ & 1.000 & .685 \\
\hline 10 & $\begin{array}{l}\text { Etika atasan menginstruksikan pegawai } \\
\text { dengan baik } \mathrm{X}_{10}\end{array}$ & 1.000 & .471 \\
\hline 11 & Atribut mensyaratkan status tertentu $\mathrm{X}_{11}$ & 1.000 & .507 \\
\hline 12 & $\begin{array}{l}\text { Sukar dan Mudahnya Mendapatkan tugas } \\
\mathrm{X}_{12}\end{array}$ & 1.000 & .463 \\
\hline 13 & Lingkungan Kerja $\mathrm{X}_{13}$ & 1.000 & .533 \\
\hline 14 & Pelatihan $\mathrm{X}_{14}$ & 1.000 & .662 \\
\hline 15 & $\begin{array}{l}\text { Sikap menunjang rasa puas atau tidak puas } \\
\mathrm{X}_{15}\end{array}$ & 1.000 & .650 \\
\hline 16 & Team work $\mathrm{X}_{16}$ & 1.000 & .359 \\
\hline 17 & Komunikasi antar pegawai dan atasan $\mathrm{X}_{17}$ & 1.000 & .489 \\
\hline 18 & $\begin{array}{l}\text { Atasan mendengar dan memahami } \\
\text { pegawai } \mathrm{X}_{18}\end{array}$ & 1.000 & .701 \\
\hline 19 & Hari libur $\mathrm{X}_{19}$ & 1.000 & .648 \\
\hline 20 & Askes, cuti dan dana pensiun $\mathrm{X}_{20}$ & .589 \\
\hline & \multicolumn{1}{|c|}{${ }_{10}$} & \\
\hline
\end{tabular}

Sumber : Data diolah

Hasil ekstrasi dari berbagai variabel yang bisa dijelaskan untuk variabel dapat kesempatan memperoleh pengalaman sebesar 70,7\%, kesempatan meningkatkan kemampuan kerja sebesar $62,9 \%$, keamanan bekerja sebesar $62 \%$, kenyamanan bekerja sebesar 72,7\%, gaji yang menyebabkan ketidakpuasan sebesar 39,3\%, jarangnya mengekspresikan kepuasan dengan sejumlah uang sebesar 62\%, perusahaan dan manajeman yang memberikan situasi stabil sebesar 57,6\%, penilaian instansi dan promosi jabatan sebesar 55,2\%, supervisi atau pengawasan sebesar $68,5 \%$, etika atasan 
menginstruksikan pegawai dengan baik $47,1 \%$, atribut mensyaratkan status tertentu sebesar 50,7\%, sukar dan mudah mendapatkan tugas sebesar 46,3\%, lingkungan kerja sebesar $53,3 \%$, pelatihan $62,2 \%$, sikap menunjang rasa puas atau tidak puas sebesar $65 \%$, team work sebesar 35,9\%, komunikasi antar pegawai dan atasan sebesar 48,9\%, atasan mendengar dan memahami pegawai sebesar
70,1\%, hari libur sebesar 64,8\%, akses cuti dan dana pensiun sebesar $58,9 \%$.

\section{Initial Eigenvalue}

Initial Eigenvalue bertujuan untuk mengetahui kemampuan seluruh variabel untuk membentuk kelompok baru, dengan catatan nilai Initial Eigenvalue harus bernilai 1 atau pembulatannya. Tabel-3 menjelaskan proses dari nilai Initial Eigenvalue.

Tabel-3: Nilai Initial Eigenvalue

\begin{tabular}{|c|c|c|c|c|c|c|c|c|c|}
\hline \multirow{2}{*}{ Component } & \multicolumn{3}{|c|}{ Intitail Eigentalues } & \multicolumn{3}{|c|}{$\begin{array}{c}\text { Extraction Suns of Squared } \\
\text { Loading }\end{array}$} & \multicolumn{3}{|c|}{$\begin{array}{c}\text { Rotation Sums Of Squared } \\
\text { Loading }\end{array}$} \\
\hline & Total & $\begin{array}{l}\text { Toof } \\
\text { Variance }\end{array}$ & $\begin{array}{c}\text { Cumulative } \\
\%\end{array}$ & $\begin{array}{l}\text { Yoof } \\
\text { Varanace }\end{array}$ & Total & $\begin{array}{c}\text { Cumuafive } \\
\%\end{array}$ & Total & $\begin{array}{c}\text { Yoof } \\
\text { Varanare }\end{array}$ & $\begin{array}{c}\text { Cumulative } \\
\text { \% }\end{array}$ \\
\hline 1 & 5.344 & 26.703 & 26.713 & 5.341 & 26.703 & 26.713 & 3.390 & 16,950 & 16.950 \\
\hline 2 & 2.024 & 10.122 & 36.825 & 20.24 & 10.122 & 36.825 & 2.558 & 12.791 & 29,742 \\
\hline 3 & 1.882 & 8.912 & 45.737 & 1.782 & 8.912 & 45.737 & 2.386 & 11,932 & 41.674 \\
\hline 4 & 1.288 & 6.42 & 52.179 & 1.288 & 6.412 & 52.179 & 1.994 & 8.968 & 50.642 \\
\hline$j$ & 1,48 & 5.729 & 57918 & 1.148 & 5.72 & 57.98 & 1.455 & 7.276 & 57.916 \\
\hline
\end{tabular}

Dari 20 variabel yang dianalisa, masingmasing variabel mempunyai satu varian, maka total varian $20 \times 1=20$, jika variabel - variabel tersebut diringkas menjadi satu faktor maka nilainya adalah sebesar 5.341, dua faktor 2.024, tiga faktor 1.782 , empat faktor 1.288 dan lima faktor maka nilainya adalah 1.148 atau dibulatkan menjadi 1. Kemudian tabel diatas juga dapat menjelaskan bahwa hanya lima faktor yang terbentuk. Karena lima faktor tersebut angka eigenvalue berada diatas 1 . Artinya hasil analisis, mengelompokan dari 20 variabel menjadi lima faktor. Screeplot dari data tersebut dapat dilihat pada gambar 3 .

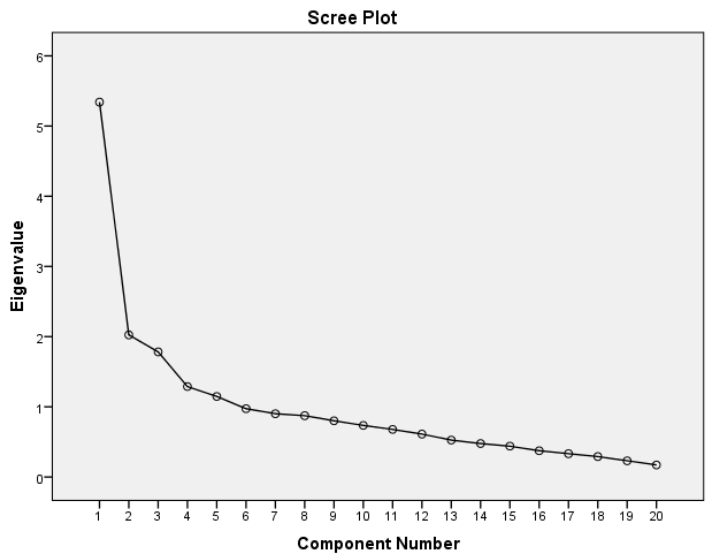

Component Matrix

Gambar-3: Screeplot Eigenvalue 
Component Matrix menunjukkan distribusi dua puluh variabel tersebut pada lima komponen utama, sedangkan angka yang ada pada tabel-4 adalah factor loading atau besar korelasi antara suatu variabel. Tabel-4 berikut menjelaskan hasil compenent matrix dari penelitian ini.

Tabel-4: Component Matrix

\begin{tabular}{|c|c|c|c|c|c|c|}
\hline \multirow{2}{*}{ No } & \multirow{2}{*}{ Variabel } & \multicolumn{5}{|c|}{ Component } \\
\hline & & 1 & 2 & 3 & 4 & 5 \\
\hline 1 & $\begin{array}{l}\text { Kesempatan memperoleh } \\
\text { pengalaman } \mathrm{X}_{1}\end{array}$ & .537 & -.634 & -.050 & .017 & 122 \\
\hline 2 & $\begin{array}{l}\text { kesempatan menigkatkan } \\
\text { kemampuan kerja } \mathrm{X}_{2}\end{array}$ & .695 & -.153 & -.012 & -.340 & .085 \\
\hline 3 & keamanana bekerja $X_{3}$ & .399 & -330 & -.167 & .135 & .553 \\
\hline 4 & Kenyamanan bekerja $X_{4}$ & .746 & -.066 & -396 & -.072 & -.064 \\
\hline 5 & $\begin{array}{ll}\text { Gaji } & \text { menyebabkan } \\
\text { ketidakpuasan } \mathrm{X}_{5}\end{array}$ & .466 & .004 & .387 & .019 & .159 \\
\hline 6 & $\begin{array}{l}\text { Jarangnya mengekspresikan } \\
\text { kepuasan dengan sejumlah } \\
\text { uang } X_{6}\end{array}$ & .743 & .142 & -.154 & .114 & -.105 \\
\hline 7 & $\begin{array}{l}\text { Perusahaan dan manajeman } \\
\text { yang memberikan situasi } \\
\text { stabil } X_{7}\end{array}$ & .554 & -.149 & -.337 & -.092 & -.354 \\
\hline 8 & $\begin{array}{l}\text { Penilaian instansi promosi } \\
\text { jabatan } \mathrm{X}_{8}\end{array}$ & .448 & -.190 & .541 & .147 & .037 \\
\hline 9 & $\begin{array}{l}\text { Supervisi atau pengawasan } \\
\mathrm{X}_{9}\end{array}$ & .290 & -.297 & .443 & -.055 & -.559 \\
\hline 10 & $\begin{array}{lr}\text { Etika } & \text { atasan } \\
\text { menginstruksikan } & \text { pegawai } \\
\text { dengan baik } X_{10} & \\
\end{array}$ & .541 & .192 & .151 & -.309 & .151 \\
\hline 11 & $\begin{array}{l}\text { Atribut mensyaratkan status } \\
\text { tertentu } X_{11}\end{array}$ & .443 & -.055 & .496 & -.109 & .222 \\
\hline 12 & $\begin{array}{l}\text { Sukar dan Mudahnya } \\
\text { Mendapatkan tugas } \mathrm{X}_{12}\end{array}$ & .401 & .173 & .233 & .244 & -.397 \\
\hline 13 & Lingkungan Kerja $X_{13}$ & .425 & .250 & .313 & -.388 & .203 \\
\hline 14 & Pelatihan X14 & .546 & .525 & -.259 & -.129 & -.066 \\
\hline 15 & $\begin{array}{l}\text { Sikap menunjang rasa puas } \\
\text { atau tidak puas } \mathrm{X}_{15}\end{array}$ & .683 & .067 & -.419 & -.050 & -.036 \\
\hline 16 & Team work $X_{16}$ & .423 & .276 & .255 & -.151 & -.127 \\
\hline 17 & $\begin{array}{l}\text { Komunikasi antar pegawai } \\
\text { dan atasan } \mathrm{X}_{17}\end{array}$ & .383 & .148 & .206 & .528 & -.015 \\
\hline 18 & $\begin{array}{l}\text { Atasan mendengar dan } \\
\text { memahami pegawai } \mathrm{X}_{18}\end{array}$ & .564 & -.549 & -.188 & .203 & -.068 \\
\hline 19 & Hari libur $\mathrm{X}_{19}$ & .367 & .260 & .009 & .642 & .183 \\
\hline 20 & $\begin{array}{lrrr}\begin{array}{l}\text { Askes, cuti } \\
\text { pensiun } \mathrm{X}_{20}\end{array} & & \\
\end{array}$ & .342 & .664 & -.110 & .101 & .094 \\
\hline
\end{tabular}

Sumber : Data diolah

\section{Rotated Component Matrix}

Rotated component matrix walaupun telah terbentuk faktor-faktor, namun perlu dilakukan rotasi untuk memperjelas variabelvariabel mana yang masuk kedalam tiap-tiap faktor. Banyak sekali factor loading yang

berubah setelah mengalami rotasi menjadi lebih kecil atau lebih besar. Tabel-5 menjelaskan rotated component matrix dari 20 variabel. 
Tabel-5: Related component matrix

\begin{tabular}{|c|c|c|c|c|c|c|}
\hline \multirow{2}{*}{ No } & \multirow{2}{*}{ Variabel } & \multicolumn{5}{|c|}{ Component } \\
\hline & & 1 & 2 & 3 & 4 & 5 \\
\hline 1 & $\begin{array}{ll}\text { Kesempatan } & \text { memperoleh } \\
\text { pengalaman } X_{1} & \end{array}$ & 211 & 163 & .788 & -.015 & .124 \\
\hline 2 & $\begin{array}{l}\text { kesempatan menigkatkan } \\
\text { kemampuan kerja } \mathrm{X}_{2}\end{array}$ & .487 & .497 & .357 & -.115 & .065 \\
\hline 3 & keamanana bekerja $X_{3}$ & .125 & .181 & .629 & .170 & -.383 \\
\hline 4 & Kenyamanan bekerja $\mathrm{X}_{4}$ & .766 & .132 & .341 & .081 & .019 \\
\hline 5 & $\begin{array}{l}\text { Gaji menyebabkan } \\
\text { ketidakpuasan } \mathrm{X}_{5}\end{array}$ & .037 & .531 & .181 & .249 & .122 \\
\hline 6 & $\begin{array}{lll}\text { Jarangnya } & \text { mengekspresikan } \\
\text { kepuasan } & \text { dengan } & \text { sejumlah } \\
\text { uang } \mathrm{X}_{6} & \\
\end{array}$ & .641 & .226 & .158 & .345 & .120 \\
\hline 7 & $\begin{array}{l}\text { Perusahaan dan manajeman } \\
\text { yang memberikan situasi } \\
\text { stabil } X_{7}\end{array}$ & .659 & -.041 & .249 & -.047 & 275 \\
\hline 8 & $\begin{array}{l}\text { Penilaian instansi promosi } \\
\text { jabatan } \mathrm{X}_{8}\end{array}$ & -.107 & 483 & .314 & .304 & 342 \\
\hline 9 & $\begin{array}{l}\text { Supervisi atau pengawasan } \\
\mathrm{X}_{9}\end{array}$ & .015 & .192 & .152 & -.039 & .789 \\
\hline 10 & $\begin{array}{lr}\begin{array}{l}\text { Etika } \\
\text { menginstruksikan } \\
\text { dengan baik } X_{10}\end{array} \text { pegawai } \\
\end{array}$ & .341 & .595 & .011 & .010 & -.027 \\
\hline 11 & $\begin{array}{l}\text { Atribut mensyaratkan status } \\
\text { tertentu } X_{11}\end{array}$ & -.052 & .653 & .210 & .137 & .122 \\
\hline 12 & $\begin{array}{l}\text { Sukar dan Mudahnya } \\
\text { Mendapatkan tugas } X_{12}\end{array}$ & .231 & .136 & -.095 & .392 & .478 \\
\hline 13 & Lingkungan Kerja $\mathrm{X}_{13}$ & .178 & .700 & -.095 & -.044 & -.036 \\
\hline 14 & Pelatihan $\mathrm{X}_{14}$ & .697 & .249 & -.265 & .183 & -.099 \\
\hline 15 & $\begin{array}{l}\text { Sikap menunjang rasa puas } \\
\text { atau tidak puas } \mathrm{X}_{15}\end{array}$ & .757 & .111 & .217 & .122 & -.057 \\
\hline 16 & Team work $\mathrm{X}_{16}$ & .260 & .447 & -.167 & & .220 \\
\hline 17 & $\begin{array}{l}\text { Komunikasi antar pegawai } \\
\text { dan atasan } \mathrm{X}_{17}\end{array}$ & .075 & .122 & .080 & .661 & .161 \\
\hline 18 & $\begin{array}{l}\text { Atasan mendengar dan } \\
\text { memahami pegawai } X_{18}\end{array}$ & .349 & -.041 & .716 & .138 & .214 \\
\hline 19 & & .137 & .034 & .072 & .780 & -.119 \\
\hline 20 & $\begin{array}{l}\text { Askes, cuti dan dana pensiun } \\
\mathrm{X}_{20}\end{array}$ & .414 & .222 & -.391 & .405 & -.226 \\
\hline
\end{tabular}

Sumber : Data diolah

\section{Component Transformation Matrix}

Compenent

transformation matrix adalah hubungan korelasi paling tinggi. Tabel-6 menunjukkan antara variabel dan komponen yang memiliki

hubungan component transformation matrix.

\section{Tabel-6: Component Transformation Matrix}

\begin{tabular}{|c|c|c|c|c|c|}
\hline Component & $\mathbf{1}$ & $\mathbf{2}$ & $\mathbf{3}$ & $\mathbf{4}$ & $\mathbf{5}$ \\
\hline 1 & $\mathbf{. 6 8 2}$ & .514 & .371 & .320 & .175 \\
\hline 2 & .237 & .187 & $\mathbf{. 8 6 2}$ & .326 & -.244 \\
\hline 3 & -.611 & $\mathbf{. 6 2 3}$ & -.096 & .168 & .448 \\
\hline 4 & -.189 & -.427 & .169 & $\mathbf{. 8 6 7}$ & .047 \\
\hline 5 & -.263 & .360 & .285 & .110 & $\mathbf{. 8 4 1}$ \\
\hline
\end{tabular}

Sumber :data diolah

\section{Component Plot in Rotated Space}

Gambar-4 menunjukkan bahwa semua variabel berada jauh dari titik 0.50 . Baik pada komponent satu, dua, tiga, empat, dan lima. Dua puluh variabel tersebut berkelompok menjadi satu, sehingga dapat diartikan bahwa semua variabel tersebut relevan untuk mempengaruhi kepuasan kerja. 


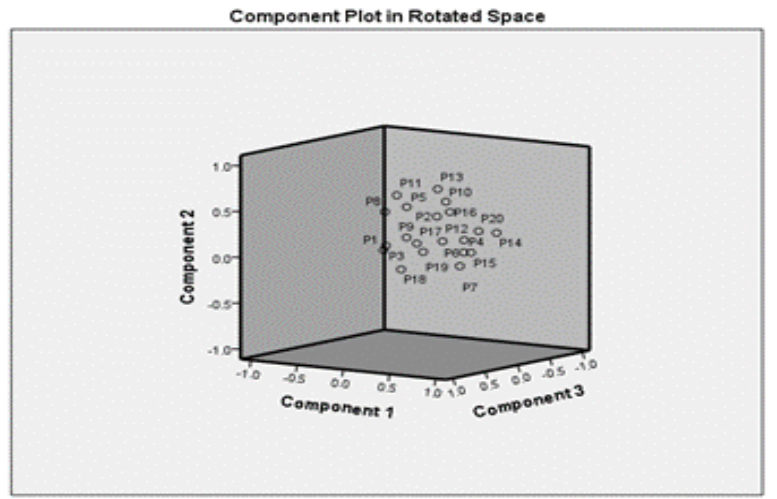

Gambar-4: Component Plot in Rotated Space

\section{KESIMPULAN DAN SARAN}

\section{Kesimpulan}

Berdasarkan hasil penelitian, kesimpulan dari 20 (dua puluh) variabel yang menjadi faktor dalam kepuasan kerja Pegawai Negeri Sipil di Kota Bekasi, terdapat 5 (lima) faktor utama yang mempengaruhi kepuasan kerja yaitu faktor budaya organisasi, faktor cara kerja, faktor kondisi kerja, faktor komunikasi, dan faktor pengawasan kerja.

\section{Saran}

Sebagai saran untuk meningkatkan kepuasan kerja yang harus dilakukan oleh instansi pemerintah, yaitu memperhatikan 5 (lima) faktor yang terbentuk, yaitu budaya organisasi, cara kerja, kondisi kerja, komunikasi, dan pengawasan kerja. Kepuasan kerja pegawai dapat ditingkatkan dengan faktor budaya organisasi dan cara kerja di dalam instansi pemerintah. Faktor budaya organisasi dan cara kerja yang baik membuat pegawai memiliki tingkat kepuasan kerja yang tinggi, sehingga instansi pemerintah sebaiknya memperhatikan dan mempertahankan terhadap kedua faktor tersebut agar kepuasan kerja pegawai bertambah atau menjadi lebih baik dengan bidang dan kemampuan pegawai dalam melayani masyarakat.

\section{DAFTAR PUSTAKA}

Badriyah, Mila. 2017. Manajemen Sumber Manusia. Bandung. CV Pustaka Setia Dessler, Gary. 2015. Manajemen Sumber Daya Manusia. Jakarta. Salemba Empat.

Flippo. B., Edwin, (2013), Personal Management, Mc Graw Hill, New York.

Ganyang, Machmed Tun. 2018. Manajemen Sumber Daya. Bogor . In Media

Hamali, Arif Yusuf. (2018). Pemahaman Manajemen Sumber Daya Manusia. Yogyakarta. Center for Academic Publishing Service.

Priansa, Donni Juni. 2014. Perencanaan dan Pengembangan Sumber Daya Manusia. Bandung. Alfabeta Press

Robbins, Stephen P \& Timothy A. Judge. 2015. Perilaku Organisasi. Jakarta. Salemba Empat

Santoso, Singgih. 2015. Statistik Multivariat. Jakarta. PT Elex Media Komputindo.

Sinambela, Lijan Poltak. 2016. Manajemen Sumber Daya Manusia Membangun Tim Kerja yang Solid untuk Meningkatkan Kinerja. Jakarta. Bumi Aksara.

Sutrisno, Ed. 2017. Manajemen Sumber Daya Manusia. Jakarta. Penerbit Erlangga. 
Sugiyono. 2017. Metode Penelitian Wibowo. 2016. Manajeman Kinerja. Kuantitatif, kualitatif dan $R \& D$. Jakarta. Katalog dalam Terbitan Bandung. Alfabeta Press. (KDT). Edisi Kelima. 